\title{
The food niche overlap of five fish species in the Úpoř brook (Central Bohemia)
}

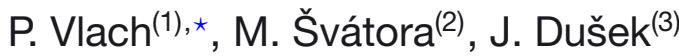 \\ Received February 25, 2013 \\ Revised June 19, 2013 \\ Accepted July 24, 2013
}

\section{ABSTRACT}

Key-words: The diet and food niche overlap of five fish species in the Úpoŕ brook food competition, brown trout, bullhead, chub, dace, stone loach, Mtot $_{p}$ was evaluated. The supply of food represented by benthos was studied, and the proportion of total food particles in the intestine of brown trout Salmo trutta L., chub Squalius cephalus (L.), dace Leuciscus leuciscus (L.), bullhead Cottus gobio (L.) and stone loach Barbatula barbatula (L.) was measured. Evaluations were performed using a new index $\left(\right.$ Mtot $\left._{p}\right)$. All fish species except stone loach exhibited a balanced consumption of the food supply. The food components were systematically grouped, but no differences in the ingestion of these groups were found. However, a new approach in the evaluation of food competition based on observation of species-specific preferences/avoidance in ingestion of food particles was applied. The particles were divided into four ecological categories according to their availability for fish. Brown trout concentrated on easily accessible sources of benthos or that hiding below stones, and also distinctly preyed on terrestrial insects. Chub displayed a similar feeding habit, though concentrating more on drift and allochthonous sources. The food spectrum of dace was mostly composed of easily accessible benthic organisms, consuming fewer hidden benthos and terrestrial insects. The food of bullhead and stone loach was similar, both preferring benthos. Bullhead consumed hidden species while stone loach consumed more accessible species rather than hidden ones.

\section{RÉSUMÉ}

Le chevauchement de niche alimentaire de cinq espèces de poissons dans le ruisseau Úpoř (Bohême centrale)

\begin{abstract}
Mots-clés : concurrence alimentaire, truite, chabot, chevesne,

Le régime alimentaire et le chevauchement de niche alimentaire de cinq espèces de poissons dans le ruisseau Úpoř été évalués. La disponibilité en nourriture représentée par le benthos a été étudiée, et la proportion de toutes les particules alimentaires dans l'intestin de la truite Salmo trutta L., du chevesne Squalius cephalus (L.), de la vandoise Leuciscus leuciscus (L.), du chabot Cottus gobio (L.) et loche franche Barbatula barbatula (L.) a été mesurée. Les évaluations ont été effectuées en utilisant un nouvel indice $\left(\right.$ Mtot $\left._{p}\right)$. Toutes les espèces de poissons à
\end{abstract}

(1) Center of Biology, Geosciences and Envigogika, Faculty of Education of the University of West Bohemia, Klatovská 51, 30619 Plzeň, Czech Republic

(2) Department of Zoology, Faculty of Biological Sciences, Charles University, Viničná 7, CZ-128 44, Praha 2, Czech Republic

(3) DAPHNE CZ - Institute of Applied Ecology, Husova 45/622, 37005 České Budějovice, Czech Republic

* Corresponding author: vlach.pavel@mybox.cz 
vandoise, loche franche, Mtot $_{p}$ l'exception de la loche franche présentaient une consommation équilibrée de la nourriture disponible. Les composants alimentaires ont été regroupés suivant les ordres ou classes, mais aucune différence dans l'ingestion de ces groupes n'a été trouvée. Cependant, une nouvelle approche dans l'évaluation de la compétition alimentaire basée sur l'observation des préférences / évitement à l'ingestion de particules alimentaires spécifiques à chaque espèce a été appliquée. Les particules ont été réparties en quatre catégories écologiques en fonction de leur disponibilité pour les poissons. La truite se tourne vers des sources facilement accessibles du benthos ou cachées en dessous des pierres, et significativement vers les insectes terrestres. Le chevesne affiche des habitudes alimentaires similaires, bien que se concentrant plus sur la dérive et les sources allochtones. Le spectre alimentaire des vandoises était principalement composé d'organismes benthiques facilement accessibles, consommant moins de benthos cachés et d'insectes terrestres. La nourriture du chabot et de la loche franche étaient similaires, les deux préfèrent le benthos. Le chabot consomme des espèces cachées alors que la loche franche consomme des espèces accessibles, plutôt que celles qui sont cachées.

\section{INTRODUCTION}

During complex studies of fish assemblages, one cannot disregard the trophic demands of particular species and possible competition between them. Often, basic parameters of fish assemblages such as abundance and biomass can be the result of food competition (Holmen et al., 2003) as well as the distribution of species and their preference of microhabitats (Cavalli et al., 1998; Fischer, 2000; Hestagen and Heggenes, 2002; Jansen et al., 2002). Interspecies trophic competition among morphologically similar species or species using the same microhabitats (Adámek et al., 2003; Hardwood et al., 2001; Pouilly et al., 2003; Volpe et al., 2001), or even other species (Baltz et al., 1982; Holmen et al., 2003) is generally expected and has often been demonstrated.

Food competition has often been discussed in the literature (Copp et al., 1994; Dyk, 1932; Fischer, 2000; Gatz et al., 1987; Maitland, 1965; Welton et al., 1991). Holmen et al. (2003) highlighted the fact that the most effective method for discovering competition is to compare sympatric and allopatric populations of evaluated species. Some authors have found it most appropriate to carry out experiments to evaluate the selectivity of a given species to a certain food component (Holmen et al., 2003; Jansen et al., 2002). In this light, it is advisable to observe the specifics of the food supply when evaluating fish diets. Not even large overlaps in food components necessarily mean a high level of competition. The species observed could have merely been consuming the same abundantly available food components (Holmen et al., 2003).

In this work, the food of five fish species (brown trout Salmo trutta, chub Squalius cephalus, dace Leuciscus leuciscus, stone loach Barbatula barbatula and common bullhead Cottus gobio) was studied. All these fish species are common in the stream studied, and many authors have studied diet and/or competition in these species (Albertová, 1982; Cavalli et al., 1998; Dyk, 1932, 1956; Fochetti et al., 2008; Hesthagen et al., 2004; Horton, 1961; Hughes et al., 2003; L'abée-Lund et al., 2002; Legalle et al., 2005; Maitland, 1965; Markovič et al., 2007; Saksgard and Hesthagen, 2004; Yevsin and Ivanov, 1979).

The aim of this work was to examine the diet of these five fish species and to evaluate the level of competition as the overlap in their food niches. Moreover, a new approach was used to identify food competition: in addition to systematically categorized food particles, a comparison in the utilization of four food categories (based on their availability for fish) was applied.

\section{MATERIAL AND METHODS}

The study was conducted in the Úpoř brook. This brook is a right-hand tributary of the Berounka River (Central Bohemia), into which it flows near the village of Týrov. The drainage 


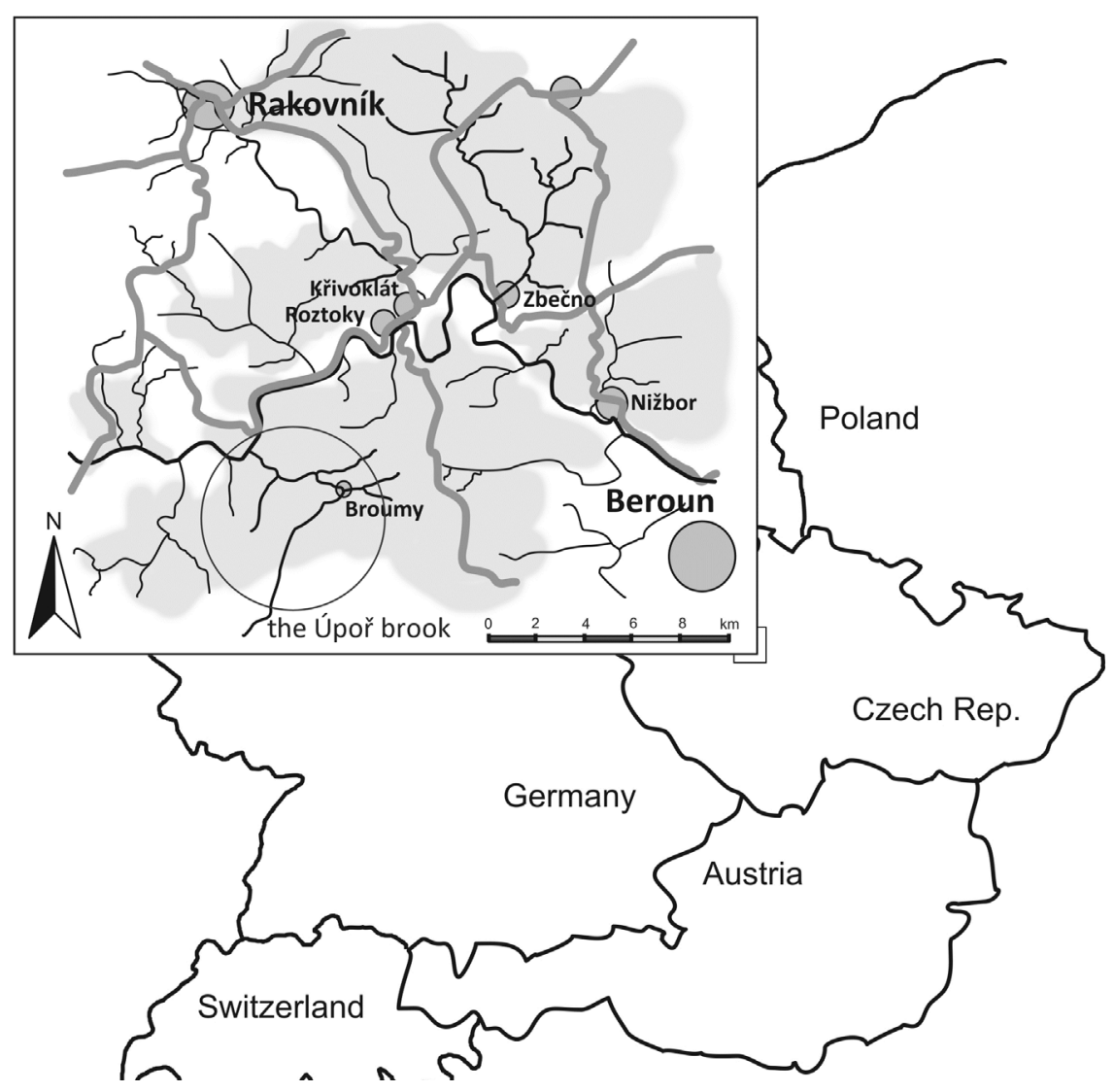

Figure 1

Map of the Úpor brook.

\section{Table I}

Length and weight structure of the examined fish (mean, SD...standard deviation, min...minimum, max...maximum).

\begin{tabular}{|l|c|cccc|cccc|}
\cline { 3 - 10 } \multicolumn{1}{c|}{} & \multicolumn{4}{c|}{ length $(\mathrm{mm})$} & \multicolumn{4}{c|}{ weight (g) } \\
\hline Species & N & mean & SD & min & max & mean & SD & min & max \\
\hline S. trutta & 164 & 120.8 & 41.8 & 46 & 270 & 38.3 & 41.3 & 0.8 & 250 \\
S. cephalus & 56 & 155.5 & 40.1 & 79 & 263 & 83.7 & 66.2 & 9.5 & 352 \\
L. leuciscus & 49 & 135.1 & 44.8 & 60 & 194 & 55.7 & 41.4 & 2.1 & 125 \\
B. barbatula & 34 & 99.6 & 16.2 & 64 & 125 & 11.1 & 4.3 & 3.2 & 18.3 \\
C. gobio & 38 & 83 & 19.1 & 36 & 108 & 13.9 & 7.7 & 0.75 & 27 \\
\hline
\end{tabular}

area is $39.5 \mathrm{~km}^{2}$, the length of the flow is $11.2 \mathrm{~km}$ and the average flow in the estuary is $0.08 \mathrm{~m}^{3} \cdot \mathrm{s}^{-1}$. The brook is typically heterogeneous, divided into pools and rapids and riffle areas. The brook is a part of the Krrivoklátsko Landscape Protected Area, Týrov National Nature Reserve, UNESCO Biosphere Reserve (see Figure 1) and is not managed by fishery organizations.

The food of the dominant species of fish assemblages in the Úpoř brook mentioned above, e.g. brown trout, chub, dace, bullhead and stone loach, was investigated. Food was evaluated for 164 brown trout individuals, 56 chub, 49 dace, 38 bullhead, and 34 stone loach. The length and weight structure of the samples is shown in Table I.

Fishing was performed during a long-term sampling campaign from 1999-2004. In total, 181 samples in 35 different localities placed along the investigated stream were taken. Fish were caught by electrofishing (devices TRA 2 - pulsed 450V; MK-1 pulsed 225/300V; LENA pulsed 225/300V), measured (standard length $-L_{c}$ (Iongitudo corporis)), weighed and fixed in $4 \%$ formaldehyde. Afterwards, autopsies of the caught fish were performed, and alimentary 
tracts were transferred to $85 \%$ ethanol, stored and later evaluated. When evaluating the intestines, the number of particular food particles and their original volume were estimated with the help of a binocular microscope. The original volume was estimated based on the volumes of particular food components as determined below.

For all species, the average proportional representation $\left(N_{p}\right)$ and the average proportional volume $\left(V_{p}\right)$ of every food component was estimated as the percentage of the overall amount or volume, respectively, of the food in the intestines. As a further indicator, the proportion of the food component as a percentage of the body weight $\left(M_{t o t} t_{p}\right)$ was calculated according to the relationship:

$$
\text { Mtot }_{p}=\frac{V_{p} \cdot\left(m-m_{1}\right)}{m}
$$

where $V_{p}$ is the proportional volume of the given food components, $m$ is the weight of the fish and $m_{1}$ is the weight without the intestines. For consistency, a $V_{p}$ value of $\rho=1 \mathrm{~kg} \cdot \mathrm{dm}^{3}$ was used in the calculations.

During 7 sampling campaigns, nine quantitative samples of benthos were taken. Samples were taken throughout the year (18.4.1998, 19.7.1998, 9.9.1998, 23.5.1999, 27.8.2001, 18.4.2002, 16.6.2003), collected in the same places where fish were caught. The collection was carried out by a combination of floating the benthos into a net, or by gathering benthos with tweezers from a delineated area of $1 \mathrm{~m}^{2}(1 \times 1 \mathrm{~m})$ or $0.25 \mathrm{~m}^{2}(0.5 \times 0.5 \mathrm{~m})$. Samples were fixed in $75 \%$ ethanol or $4 \%$ formaldehyde. Identification of particular components was carried out with a binocular microscope. Allochthonous food sources such as terrestrial insects and other terrestrial organisms and plants were not identified. The average amount and proportional volume of benthos components was calculated as the weighted mean of particular components from all samples. The density of particular components was calculated according to the volume of particular components (acquired using direct measurements of volume and linear regressions between the volume and number of the given components on the overall contents of the intestines of each fish) and their number at the site.

The use of the macrozoobenthos supply was evaluated by comparing the average proportion of each individual constituent in the supply and the average (weighted mean) proportion of the food constituents in the intestines of all specimens of each species $\left(V_{p}\right)$ using $\chi^{2}$ tests. Significance was tested at the level of $5 \%$.

Interspecific food competition was evaluated by comparing the particular food components as a percentage of body weight $\left(\right.$ Mtot $\left._{p}\right)$ for each species.

All food components were first grouped into families and 4 food categories according to where fish could most easily find the given food component, as follows:

- Category I included food sources living hidden under stones or in the substrata (mud, sand) and staying hidden except for the time of hatching, pupating or during possible disturbances. This category included gammarids, Sialis fuliginosa, caddisflies from the families Rhyacophilidae and Hydropsychidae, mayflies from the family Heptageniidae, and finally, dipteran juveniles.

- Category II included species which are more easily accessible, that is, living on the bottom, on stones (occasionally partly under stones and therefore hidden), and sometimes migrating in the water current. This group was made up primarily of caddisflies, stoneflies and mayflies from the families Limnephilidae, Odontoceridae, Leuctridae, Nemouridae, Baetidae, Caenidae and Leptophlebiidae, as well as annelids and detritus.

- Category III consisted of drifting food particles, i.e. terrestrial plants, water coleopterans and heteropterans, fish, reptilians, amphibians, dipteran larvae and pupae from the family Culicidae, and other hyponeustic species.

- Category IV consisted of terrestrial insects and epineustic species.

One-way ANOVA and the Tukey-Kramer test were used for comparisons. The level of competition was also evaluated using Detrended Corresponding Analysis (DCA) using matrices consisting of food particle proportions $\left(\right.$ Mtot $_{r}$ ) for particular fish species.

Statistical analyses were carried out using OpenOffice software, the statistical program NCSS, and Canoco 4.5. 
Table II

Number, proportional volume and density of particular macrozoobenthos components in the Úpor brook.

\begin{tabular}{|l|c|c|c|}
\hline taxa & $\begin{array}{c}\text { number } \\
(\%)\end{array}$ & $\begin{array}{c}\text { volume } \\
(\%)\end{array}$ & $\begin{array}{c}\text { density } \\
\left(\mathrm{g} \cdot \mathrm{m}^{-2}\right)\end{array}$ \\
\hline Baetidae & 1.30 & 0.49 & 0.058 \\
Caenidae & 0.02 & 0.02 & 0.002 \\
Ephemeridae & 0.27 & 0.17 & 0.018 \\
Ephemerillidae & 0.05 & 0.002 & 0.001 \\
Heptageniidae & 8.03 & 11.53 & 1.395 \\
Leptophlebiidae & 15.46 & 6.82 & 0.815 \\
Leuctridae & 4.60 & 2.76 & 0.334 \\
Nemouridae & 0.86 & 0.62 & 0.076 \\
Perlidae & 0.02 & 0.01 & 0.018 \\
Athericidae & 0.02 & 0.16 & 0.02 \\
Ceratopogonidae/Chironomidae & 17.30 & 7.95 & 0.711 \\
Limoniidae & 0.08 & 0.002 & 0.001 \\
Simuliidae & 7.15 & 7.97 & 0.746 \\
Limnephilidae tr. Stenophylacini & 13.47 & 27.30 & 2.661 \\
Odontoceridae & 9.08 & 14.76 & 1.657 \\
Hydropsychidae/Rhyacophilidae/Philopotamidae & 4.77 & 2.95 & 0.223 \\
Sialis sp. & 1.66 & 3.47 & 0.379 \\
Gammarus sp. & 15.56 & 12.90 & 1.539 \\
Asellus sp. & 0.01 & 0.00 & 0.001 \\
Oligochaeta & 0.29 & 0.12 & 0.526 \\
\hline
\end{tabular}

\section{Table III}

Use of food components by particular fish species (as proportional volume $-V_{p}$ ). Only food particles found in digestive systems of fish are presented (i.e. $96.4 \%$ of the benthos).

\begin{tabular}{|l|c|c|c|c|c|c|}
\hline taxa/food particle & $\begin{array}{c}\text { food } \\
\text { supply (\%) }\end{array}$ & $\begin{array}{c}\text { S. trutta } \\
(\%)\end{array}$ & $\begin{array}{c}\text { S. cephalus } \\
(\%)\end{array}$ & $\begin{array}{c}\text { L. leuciscus } \\
(\%)\end{array}$ & $\begin{array}{c}\text { C. gobio } \\
(\%)\end{array}$ & $\begin{array}{c}\text { B. barbatula } \\
(\%)\end{array}$ \\
\hline plants & & 0.00 & 11.50 & 4.71 & 0.00 & 0.00 \\
detritus & & 0.00 & 2.65 & 6.11 & 0.00 & 0.00 \\
\hline Baetidae & 0.49 & 4.65 & 0.12 & 5.81 & 5.14 & 28.71 \\
Ephemeridae & 0.17 & 0.36 & 0.57 & 0.00 & 6.00 & 0.00 \\
Heptageniidae & 11.53 & 19.23 & 9.80 & 11.13 & 9.87 & 4.01 \\
Leptophlebiidae & 6.82 & 0.46 & 0.06 & 2.04 & 0.00 & 0.87 \\
Diptera & 15.98 & 11.62 & 0.72 & 25.00 & 29.43 & 15.45 \\
Limnephilidae & 27.30 & 31.68 & 70.94 & 25.97 & 40.23 & 46.10 \\
Odontoceridae & 14.76 & 19.67 & 8.22 & 25.33 & 0.00 & 0.10 \\
Hydropsychidae* & 2.95 & 0.29 & 0.00 & 0.00 & 2.97 & 0.00 \\
Sialis sp. & 3.47 & 0.93 & 0.00 & 0.27 & 0.00 & 0.00 \\
Gammarus sp. & 12.90 & 7.49 & 5.96 & 0.81 & 2.74 & 1.14 \\
\hline
\end{tabular}

* Hydropsychidae/Rhyacophilidae/Philopotamidae.

\section{RESULTS}

\section{>FOOD SUPPLY}

During the whole period, the largest component of macrozoobenthos was undoubtedly insect juveniles, comprising five orders and twenty families.

The average number, proportional volume and density of benthos are given in Table II.

\section{> FOOD SUPPLY CONSUMPTION}

In spite of some differences in the use of certain constituents, as seen in Table III (generally; fish preferred dipteran juveniles, juveniles of both caddisflies and mayflies from the families Limnephilidae and Baetidae, whereas the supply of mayflies from the family Leptophlebiidae, megalopteridians and gammarids was stable), the overall use of the food supply by all 


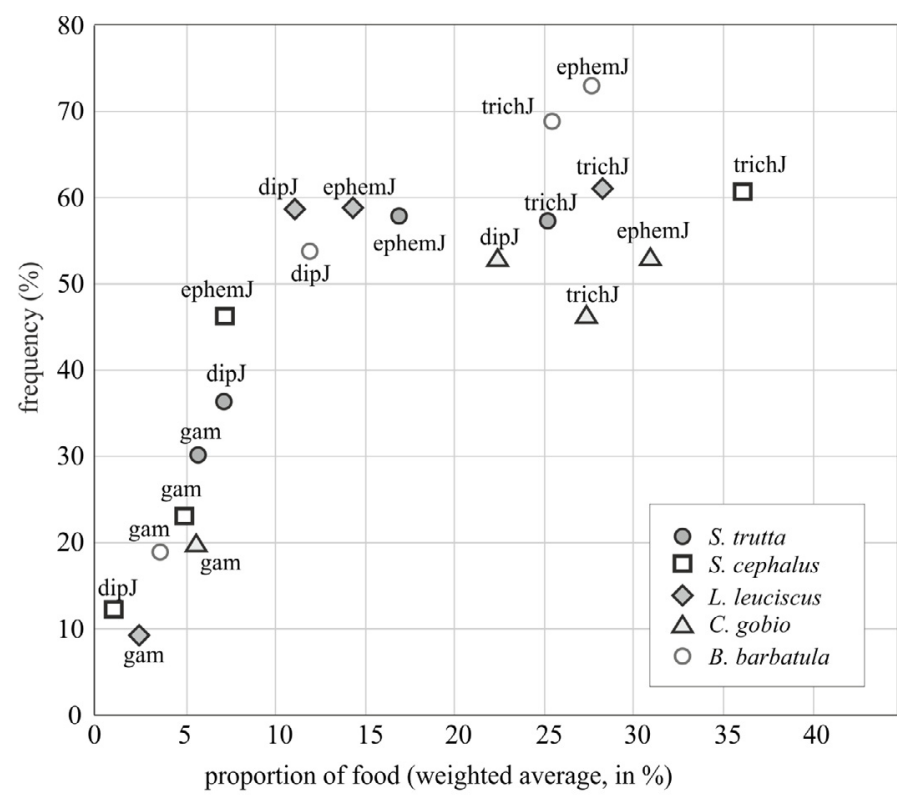

Figure 2

Frequency and proportion of some food particles in the diet of the fish species studied. trichJ Trichoptera juveniles, dipJ - Diptera juveniles, ephemJ - Ephemeroptera juveniles, gam - Gammarus sp.

species except stone loach $\left(\chi^{2}\right.$ test, $\left.P<0.05\right)$ was similar. This difference in consumption by stone loach was primarily caused by a strong preference for juveniles from the family Baetidae and, in contrast, by the lower use of juveniles of the species Odontocerum albicorne. The frequency and proportion of some of the food categories are shown in Figure 2. Both the low proportion and frequency of gammarids in all observed fish species is noticeable. On the other hand, fish frequently consumed larvae of caddisflies, which also comprised the largest proportion of their food. Differences were found in the intake of dipteran larvae, which played a dominant role in the food of dace, bullhead and stone loach, whereas they were negligible in the food of brown trout and chub. Mayfly larvae were consumed often; however, there are differences in their contribution to the overall diet of particular species.

\section{>EVALUATION OF FOOD COMPETITION}

The categories of food sources can be seen in Figure 3, showing the following significant differences resulting from ANOVA $(P<0.05)$ and the Tukey-Kramer Post-Hoc Test $(P=0.05$, Critical Value $=3.88)$ : both dace and chub utilized plants more than other species $($ d.f. $=271$, $F=17.3$ ), larvae of stoneflies were used significantly less by chub than by stone loach and bullhead (d.f. $=271, F=3.58$ ), plecopterian larvae were utilized more by stone loach than by other fish species (d.f. $=271, F=9.91$ ), and dipteran larvae were utilized more by bullhead (d.f. $=271, F=5.56$ ). Piscivory was detected only in brown trout and chub, and was only significantly different from other species in brown trout (d.f. $=271, F=3.00$ ). When evaluating the use of terrestrial insects, there seems to be a higher utilization by chub and brown trout in comparison with bullhead and stone loach (d.f. $=271, F=12.22$ ).

Other differences (molluscs, gammarids) were not statistically significant, and could have been caused by single, sporadic, or even intensive intakes.

Due to the considerable importance of some particular food components, i.e. caddisflies from the families Limnephilidae tribus Stenophylacini, Rhyacophilidae and Hydropsychidae and mayflies from the families Heptageniidae, Baetidae, Leptophlebiidae and Ephemeridae, individual comparisons were also performed.The differences in intakes of these food components, represented by the weighted average values of Mtot $_{p}$ for particular species, correspond with the results of ANOVA and the Tukey-Kramer Post-Hoc Test $(P=0.05$, Critical 


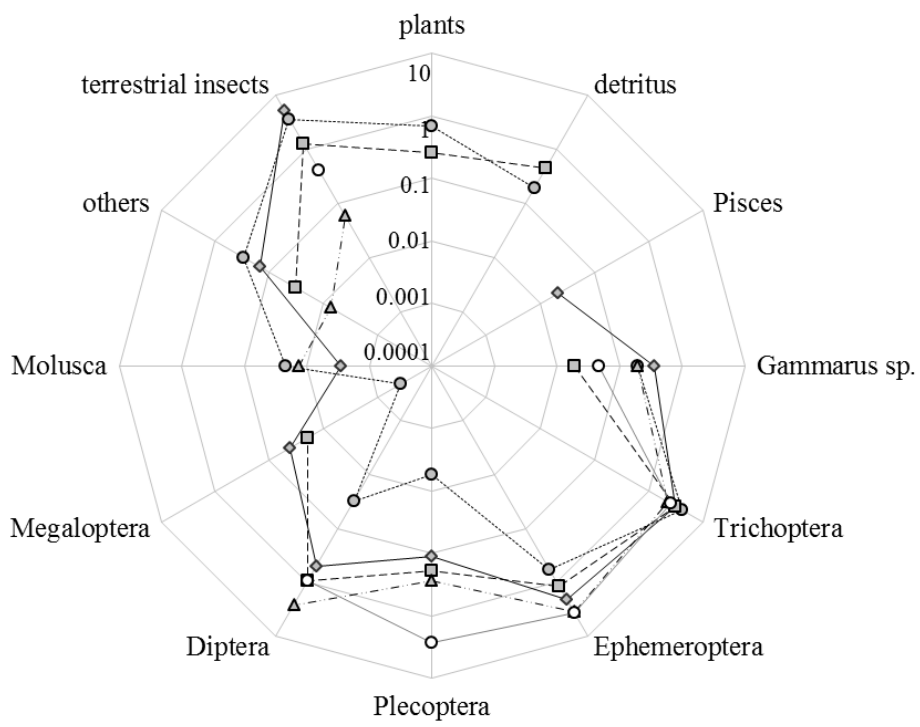

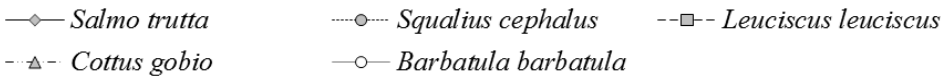

\section{Figure 3}

The use of particular food components in the diet of the studied fish species (log-transformed Mtot ${ }_{p}$ ).

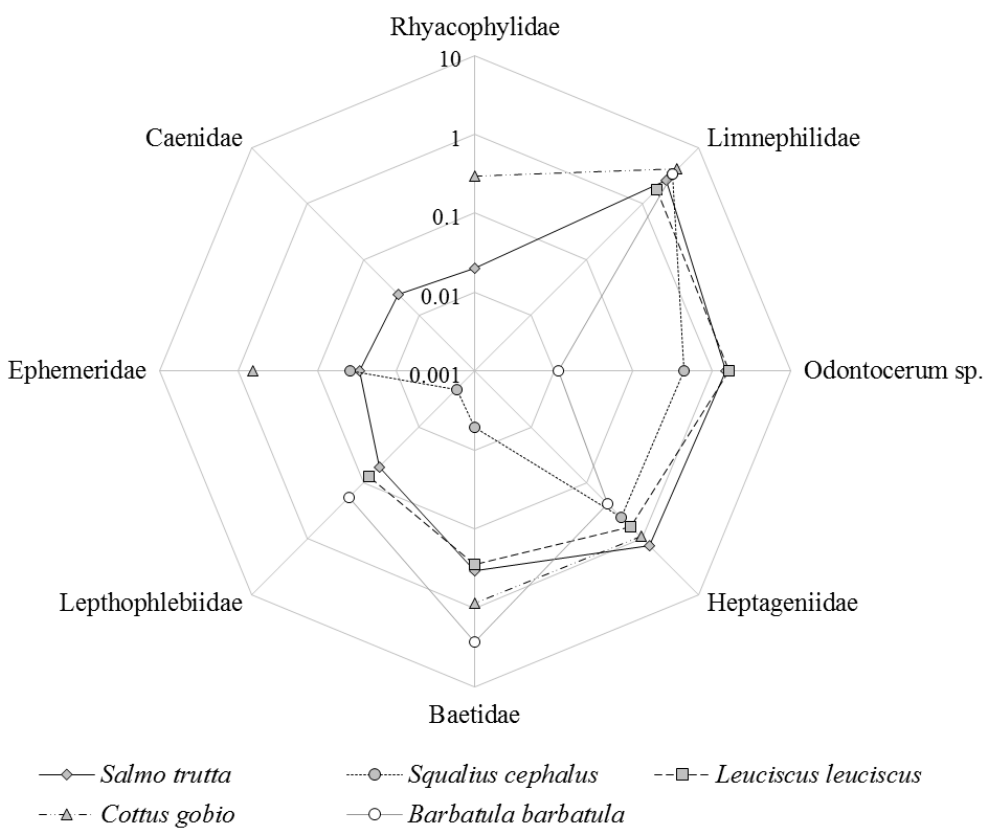

\section{Figure 4}

Use of particular families and species of macrozoobenthos in the diet of the studied fish species (logtransformed Mtot $\left._{p}\right)$.

Value $=3.88$ ) (see Figure 4). Bullhead used caddisflies from the families Rhyacophilidae and Hydropsychidae significantly more than chub and dace (d.f. $=271, F=2.93$ ), caddisflies of the genus Odontocerum were consumed less by bullhead and stone loach than by dace and brown trout ( $d . f .=271, F=3.84)$, mayflies from the family Ephemeridae were used mostly by bullhead, significantly more than by other species $(d . f .=271, F=4.96)$ and mayflies from the family Baetidae comprised a greater part of the food of stone loach than for other species (d.f. $=271, F=4.62)$. 


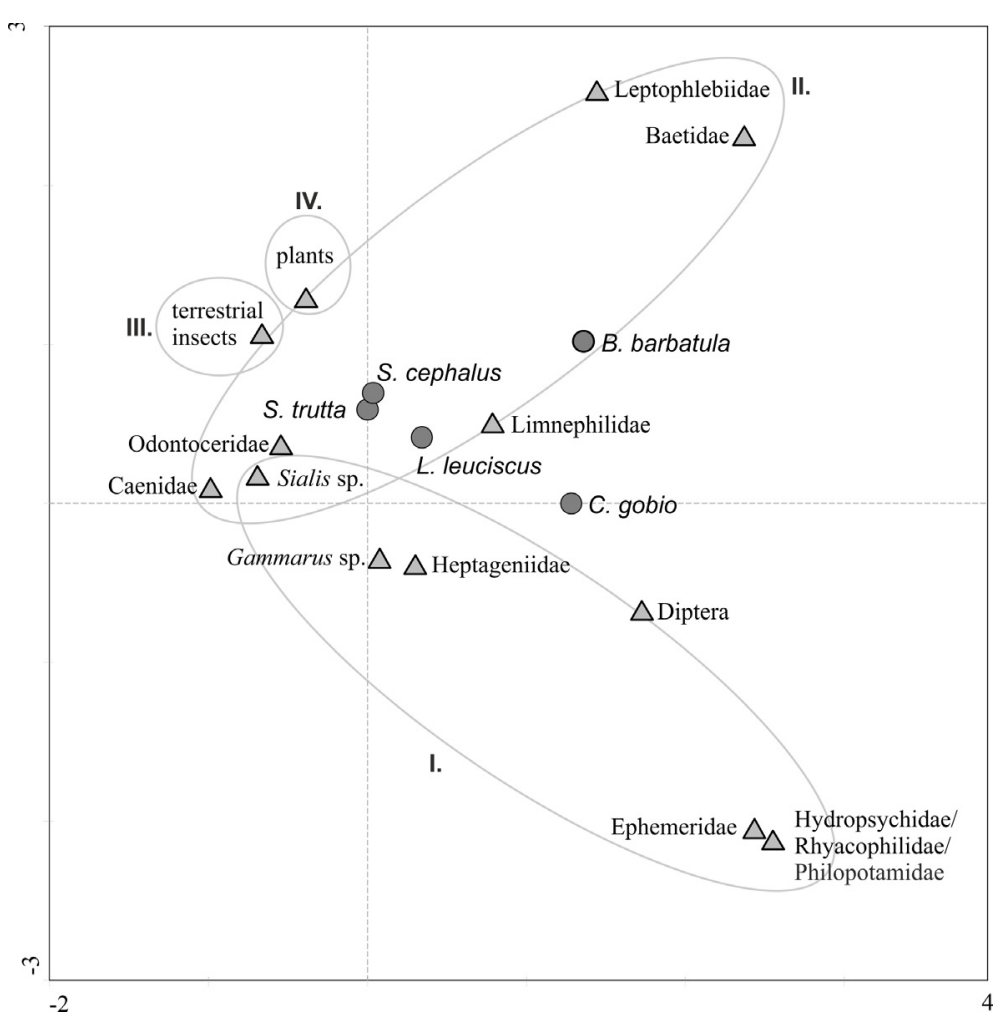

\section{Figure 5}

First and second axes of the DCA biplot (matrix fish $\times$ food components). Numerals and ovals refer to food particles summarized as food categories (I - IV): I - food sources living hidden under stones or in the substrata and usually staying hidden, II - more easily accessible, living on the bottom, on stones; III - drifting food particles (e.g. plants, water coleopterans and heteropterans, fish, etc.); IV - terrestrial insects.

The ingestion of the food components from four categories (as Mtotp) were also compared (see Material and methods), and differences were analyzed by ANOVA and the Tukey-Kramer test $(P<0.05)$ :

1. Organisms in the first category comprised a large (approximately $18 \%$ ) proportion primarily in the food of brown trout and bullhead. In the food of dace, they made up the smallest proportion (5.9\%), with the difference between brown trout and dace being significant.

2. The second category was the dominant constituent of all species. It comprised the largest percentage in the food of bullhead (80\%) and stone loach (92\%). Stone loach used this constituent significantly more than brown trout, chub and dace.

3. The third category was only represented in dace and chub, primarily caused by the large amount of water plants present in their diet, as well as the occurrence of water coleopterans, heteropterans and vertebrates in chub. Significant differences, however, were only found between chub and other species.

4. The fourth category played the largest role in the food of brown trout and chub, where it comprised over $30 \%$ of the food supply. On the other hand, for bullhead and stone loach it made up less than $1 \%$; these large differences were significant.

The categories of food and data about the use of important food components were used to evaluate competition using DCA (see Figure 5). From these analyses, it is possible to conclude that the closest relationship was between chub and brown trout. When examining the DCA results, it is clear that the food components formed gradients, which is homologous with the above-mentioned ecological food categories (see ovals in Figure 5). A relationship between bullhead and stone loach can also be seen, which are separated from the other group of brown trout-dace-chub. 
The relationship of particular species to food categories can be interpreted as follows: brown trout consumed all food sources relatively equally, with the closest relationship to easily accessible benthos or that hiding below stones, and also distinctly using terrestrial insects. Chub had almost the same food usage as brown trout, though using food from category III, i.e. drift and allochthonous sources, more than brown trout. The food spectrum of dace was most similar to chub, though consuming fewer hidden species of benthos and terrestrial insects. The main components of its food consisted of easily accessible benthic organisms. The food of bullhead was most similar to that of stone loach. Bullhead primarily used benthos, and terrestrial insects and drift the least. They also consumed hidden species more than easily accessible species. The food of stone loach was very similar to that of bullhead (minimally using drift and terrestrial insects); they consumed fewer hidden species, but more easily accessible species.

\section{DISCUSSION}

Many recent as well as older studies have focused on food competition (Copp et al., 1994; Dyk, 1932; Fischer, 2000; Fochetti et al., 2008; Gatz et al., 1987; Markovič et al., 2007), sometimes under experimental conditions (Holmen et al., 2003; Jansen et al., 2002). One common method of processing data about food components in such studies is the grouping of individual components into systematic categories, as was also done in our study. It is difficult to find conclusive differences for these systematic groups in our data; generally, all fish consumed large quantities of caddisflies, mayflies and dipteran juveniles, as has been found by, e.g., Fochetti et al. (2008), Maitland (1965), Markovič et al. (2007), Straškraba et al. (1966) and Welton et al. (1991). In the Úpoř brook mayflies comprised $34 \%$ and caddisflies $45 \%$ of the food supply, respectively, and differences in this supply and the consumption of particular species were not significant $\left(\chi^{2}\right.$ test, $\left.P>0.8\right)$. From Figure 2 , it is clear that these numerous components comprised a large proportion of the fish diets and were often ingested. This would indicate very strong competition among individual fish species with regard to benthos. For the above-mentioned reasons, competition according to particular families and individual species of benthos was also evaluated, and significant differences were found. Many of the preferences/avoidance result from the typical habitats preferred by particular fish species (Straškraba et al., 1966). This can explain, for instance, the increased use of hidden mayflies and caddisflies from the Heptageniidae, Ephemeridae and Rhycophilidae families observed in bullhead. Differences found in the consumption of the species Odontocerum albicorne (preferably selected by dace and negatively selected by bullhead and stone loach) could be influenced by the character and size of its cases whereas bullhead and stone loach preferred mayflies from the Baetidae family. Such preferences in bullhead were experimentally demonstrated by Dahl (1999). The preference of brown trout for the Baetidae family has been reported by Straškraba et al. (1966) and Teixeira and Cortes (2006). On the other hand, Zimmerman and Vondracek (2007) as well as Dahl (1999) reported strong preferences for the Gammaridae family in brown trout diets, but this was not reflected in our results.

The food of the fish species studied here did not only consist of macrozoobenthos. Fish, plants, terrestrial insects and detritus were also found in their diet. Piscivory played a very small role in the food of the fish observed, only appearing considerably in the food of brown trout (and in one case in the food of both chub and bullhead). In brown trout it comprised 2.9\% (and less than 1\% when using the weighted average). Dyk (1956) drew attention to selective piscivory in large brown trout, with reference to both stone loach and bullhead (Dyk, 1932) as food sources. In the Úpoř brook, fish (5 bullheads and 1 lamprey juvenile) were found in individuals of brown trout measuring longer than $148 \mathrm{~mm}$ (129 mm in the case of lamprey). Horton (1961) found a 12\% incidence of piscivory in the Walla stream, and Yevsin and Ivanov (1979) $7 \%$ piscivory in the river Pulonga; however, the average lengths of these samples were 600 and $400 \mathrm{~mm}$, respectively. Hesthagen et al. (2004) reported only one occurrence of piscivory in a sample of 207 brown trout from $70-120 \mathrm{~mm}$ in length. In the former Czechoslovakia, Dyk (1956) found a piscivory incidence of $12 \%$ in 641 brown trout, representing the 7 th most 
important food source. This also calls attention to the higher nutritional value of fish and the related lower frequency of food ingestion. A similar phenomenon was observed by L'abéeLund et al. (2002), who observed changes in piscivory by brown trout over a long period, and noted differences in growth in this changing population.

Piscivory in chub was identified in only one case (with 1 brown trout as prey). As for brown trout, piscivory occurs primarily in larger chub individuals (Maitland and Campbell, 1992), whereas small chub of about $160 \mathrm{~mm}$ in length were dominant in the Úpoř brook. Markovič et al. (2007) mentioned piscivory in chub aged 6 years and older. Piscivory was even identified in bullhead, with a juvenile brown trout appearing as food in one case. Sporadic piscivory in bullhead has also been mentioned by Andreasson (1971) and Hesthagen et al. (2004). Maitland and Campbell (1992) even found piscivory (juvenile individuals) in 3\% of the bullhead they examined.

Competition can also be reduced by fish preferring different microhabitats. Cavalli et al. (1998), Jansen et al. (2002), and Saksgard and Hesthagen (2004) have described the character displacement of brown trout and the brook char Salvelinus fontinalis in lakes, where brown trout concentrated on littoral and epibenthic habitats and brook char on epipelagic habitats. Hestagen and Heggenes (2002) and Hesthagen et al. (2004) also described the preference of bullhead for deeper substrata compared with brown trout. The opposite preference is generally thought to be more common, as in our location, where bullhead preferred coarse stone substrata and shallower depths. Microhabitat preferences were studied in this locality by Vlach et al. (2005).

Moreover, not only fish prefer different habitats, but the way benthos use the water column is species-specific. Hieber et al. (2003) pointed out that certain species of mayflies are often a part of drift (Rhitrogena sp., Baetis $s p$.), while others, even though also often occurring in benthos, are almost non-existent in drift (Ecdyonurus $s p$.). This is in accordance with the very different ecological demands and habitat preference of mayfly juveniles. If the main source of benthic organisms in drift is primarily disturbance due to changes in water flow (Lake, 2000) that moves substratum particles and therefore causes food items to become dislodged (Death, 2003), it is clear that crawling or swimming mayfly larvae will be dislodged more often than hidden or burrowed larvae. Although the larvae of hidden species may appear during faster flows or during hatching (Mann, 1974), from the perspective of the whole season this may be disregarded.

From the evaluation of competition with respect to benthos, it is clear that a systematic summary of food components may not always be appropriate. Therefore, in this work a new approach was also used, attempting to compare food categories while taking into account the distribution of all food components. These food categories indicate the availability of the food components for particular fish species with respect to their habitat preferences. It can be seen from Figure 5 that data about the composition of particular species evaluated by DCA showed such gradients in food ingestion that correspond to the food categories. Moreover, evaluating these categories and the consumption of particular species (or families) of benthos using DCA demonstrated further divergence in food demands. The competitor groups formed by bullhead-stone loach and chub-dace reflect two competing morphologically similar species with a preference for the same microhabitat and the same niche (Adámek et al., 2003; Gatz et al., 1987; Pouilly et al., 2003; Volpe et al., 2001).

The results from DCA, shown in Figure 5, clearly demonstrate the main findings of this study. The relatively close relationship of all species on the basis of food consumption is evident in the center of Figure 5. This resulted from the fact that benthos comprised the largest proportion in the food of all observed species, as also reported by Maitland (1965) and Straškraba et al. (1966). It can also be seen that the highest competition is between brown trout and chub, reflected in the fact that in addition to benthos they also often consumed (as rheophilic species) allochtonous material consisting of terrestrial insects from the water surface or drifting through the water column. From this point of view, the relatively low competition between the brown trout - chub - dace group and the stone loach - bullhead group is not surprising, because the second group did not consume allochtonous material. Differences between 
bullhead and stone loach are in accordance with their habitat preference and ecology, with bullhead consuming more hidden macrozoobenthos species (food category I.) than stone loach. Unlike many studies that have considered bullhead to be a strong temporary or permanent food competitor of brown trout, (Andreasson, 1971; Hestagen and Heggenes, 2002; Hesthagen et al., 2004; Holmen et al., 2003), no such relationship was found in our data. The position of dace among these species is governed by its close relationship to benthos and drifted plants and detritus. Differences between stone loach and dace (both species preferred particles in food category II.) are clear from their consumption of individual species of benthos; dace prefers larger morsels with a special preference for Odontocerum albicorne, whereas stone loach prefers smaller morsels such as stonefly and mayfly juveniles from the Baetidae and Leptophlebiidae families.

\section{ACKNOWLEDGEMENTS}

This study was supported by the Czech Ministry of Environment project (VaV SPII2D1/36/07) "Analysis and optimization proposal for trout management in the Czech Republic in relation to the special species protection and the biodiversity in protected areas" and the institutional resources of the Ministry of Education, Youth and Sports of the Czech Republic for the support of science and research.

We also appreciate the cooperation of the Agency for Nature Conservation and Landscape Protection of the Czech Republic.

\section{REFERENCES}

Adámek Z., Sukop I., Rendón P.M. and Kouřil J., 2003. Food competition between 2+ tench (Tinca tinca L.), common carp (Cyprinus carpio L.) and bigmouth buffalo (Ictiobus cyprinellus Val.) in pond polyculture. J. Appl. Ichthyol., 19, 165-169.

Albertová O., 1982. The food of rainbow trout and brown trout in the water-supply dam reservoirs Lučina and Římov. Bulletin VúRH Vodňany, 11, 127-134.

Andreasson S., 1971. Feeding habits of a sculpin (Cottus gobio L., Pisces) population. Institute of Freshwater Resources, Sweden, $51 \mathrm{p}$.

Baltz D.M., Moyle P.B. and Knight N.J., 1982. Competitive interactions between benthic stream fishes, reiffle sculpin, Cottus gulosus, and speckled dace, Rhinichthys osculus. Can. J. Fish. Aquat. Sci., 39, 1502-1511.

Cavalli L., Chappaz R. and Gilles A., 1998. Diet of Arctic charr (Salvelinus alpinus (L.)) and brown trout (Salmo trutta L.) in sympatry in two high altitude alpine lakes. Hydrobiologia, 386, 9-17.

Copp G.H., Warrington S. and deBruine Q., 1994. Comparison of diet in stone loach Barbatula barbatula (L.) and bullhead Cottus gobio (L.) in a small stream. Folia Zool., 43, 171-176.

Dahl J., 1999. Effects of a benthivorous and a drift-feeding fish on a benthic stream assemblage. Environ. Biol. Fish., 56, 443-453.

Death R.G., 2003. Spatial patterns in lotic invertebrate communiy composition: is substrate disturbance actually important? Can. J. Fish. Aquat. Sci., 60, 603-611.

Dyk V., 1932. Terrestrial insects and other foo particles in a diet of brown trout from streams of CzechMoravian Highlands, Brno, 35 p.

Dyk V., 1956. Food bases in trout waters. Czech J. Anim. Sci., 12, 985-990.

Fischer P., 2000. Test of competitive interactions for space between two benthic fish species, burbot Lota lota, and stone loach Barbatula barbatula. Environ. Biol. Fish., 58, 439-446.

Fochetti R., Argano R. and deFigueroa J.M., 2008. Feeding ecology of various age-classes of brown trout in River Nera, Central Italy. Belg. J. Zool., 132, 128-131.

Gatz A.J., Sale M.J. and Loar J.M., 1987. Habitat shifts in rainbow trout. competitive influences of brown trout. Oecologia, 7-19. 
Hardwood A.J., Metcalfe N.B., Armstrong J.D. and Griffiths W.W., 2001. Spatial and temporal effects of interspecific competition between Atlantic salmon (Salmo salar) and brown trout (Salmo trutta) in winter. Can. J. Fish. Aquat. Sci., 58, 1133-1140.

Hestagen T. and Heggenes J., 2002. Competitive habitat displacement of brown trout (Salmo trutta) and Siberian sculpin (Cottus poecilopus): the role of size and density. J. Fish. Biol., 62, 222-236.

Hesthagen T., Saksgärd R., Hegge O., Dervo B.K. and Skurdal J., 2004. Niche overlap between young brown trout (Salmo trutta) and Siberian sculpin (Cottus poecilopus) in a subalpine Norwegian river. Hydrobiologia, 512, 117-125.

Hieber M., Robinson C.T. and Euhlinger U., 2003. Seasonal and dial patterns of invertebrate drift in different alpine stream types. Freshwater Biol., 48, 1078-1092.

Holmen J., Olsen E.M. and Vollestad L.A., 2003. Intespecific competition between stream dwelling brown trout and Alpine bullhead. J. Fish. Biol., 62, 1312-1325.

Horton A., 1961. The bionomics of brown trout in a Dartmoor stream. J. Anim. Ecol., 30, 311.

Hughes F.H., Hayes J.W., Shearer K.A. and Young R.G., 2003. Testing a model of drift-feeding using thre-dimensional videography of wild brown trout, Salmo trutta, in a New Zealand river. Can. J. Fish. Aquat. Sci., 60, 1462-1479.

Jansen P.A., Slettvold H., Finstad A.G. and Lageland A., 2002. Niche segregation between Arctic char (Salvelinus alpinus) and brown trout (Salmo trutta): an experimental study of mechanisms. Can. J. Fish. Aquat. Sci., 59, 6-11.

L'abée-Lund J.H., Aass P. and Saegrov H., 2002. Long-term variation in piscivory in a brown trout population: effect of changes in available prey organism. Ecol. Freshw. Fish., 11, 206-209.

Lake P.S., 2000. Disturbance, patchiness and diversity in streams. J. N. Am. Benthol. Soc., 19, 573-592.

Legalle M., Santoul J., Figuerola J., Mastrorilli S. and Céréghino J., 2005. Factors influencing the spatial distribution patterns of the bullhead (Cottus gobio L., Teleostei Cottidae): a multi-scale study. Biodivers. Conserv., 14, 1319-1334.

Maitland P.S., 1965. The Feeding Relationships of Salmon, Trout, Minnows, Stone Loach and ThreeSpined Stickle- Backs in the River Endrick, Scotland. J. Anim. Ecol., 34, 109-133.

Maitland P.S. and Campbell R.N., 1992. Freshwater fishes of the British Isles. Harper Collins Publishers, London, $368 \mathrm{p}$.

Mann R.H.K., 1974. Observations on the age, growth, reproduction and food of the dace, Leuciscus leuciscus (L.), in two rivers in southern England. J. Fish. Biol., 6, 237-253.

Markovič G.S., Simič V.M., Ostojič A.M. and Simič S., 2007. Seasonal variation in nutrition of chub (Leuciscus cephalus L., Cyprinidae, Osteichtyes) in one reservoir of west Serbia. Proceedings for Natural Sciences, Matica Srpska, Novi Sad., 112, 107-113.

Pouilly M., Lino F., Bretenoux J.G. and Rosales C., 2003. Dietary-morphological relationships in a fish assemblage of the Bolivian Amazonian floodplain. J. Fish. Biol., 62, 1137-1158.

Saksgard R. and Hesthagen T., 2004. A 14-year study of habitat use and diet of brown trout (Salmo trutta) and Arctic charr (Salvelinus alpinus) in Lake Atnsjoen, a subalpine Norwegian lake. Hydrobiologia., 521, 187-199.

Straškraba M., Čihař J., Frank S. and Hruška V., 1966. Contribution to the Problem of Food Competition Among the Sculpin, Minnow and Brown Trout. J. Anim. Ecol., 35, 303-311.

Teixeira A. and Cortes R.M.V., 2006. Diet of stocked and wild trout, Salmo trutta: Is there competition for resources? Folia Zool., 55, 61-73.

Vlach P., Dušek J., Švátora M. and Moravec P., 2005. Fish assemblage structure, habitat and microhabitat preference of five fish species in a small stream. Folia Zool., 54, 421-431.

Volpe J.P., Anholt B.R. and Glickman B.W., 2001. Competition among juvenile Atlantic salmon (Salmo salar) and steelhead (Oncorhynchus mykiss): relevance to invasion potential in British Columbia. Can. J. Fish. Aquat. Sci., 58, 197-207.

Welton J.S., Mill C.A. and Pygott J.R., 1991. The effect of interaction between the stone loach Noemacheilus barbatulus (L.) and the bullhead Cottus gobio (L.) on prey and habitat selection. Hydrobiologia, 220, 1-7.

Yevsin V.N. and Ivanov N.O., 1979. The summer feeding of brown trout, Salmo trutta, in the Pulon'ga river (Kola Peninsula). Journal of Ichthyology, 19, 122-127.

Zimmerman J.K.H. and Vondracek B., 2007. Brown trout and food web interactions in a Minnesota stream. Freshwater Biol., 52, 123-136. 